\title{
Analisis Kemampuan Berpikir Kritis Siswa SMA Kelas X Dalam Memecahkan Masalah SPLTV
}

\author{
Benyamin, Abd. Qohar, I Made Sulandra \\ Program Studi Pascasarjana Pendidikan Matematika, Fakultas Matematika dan Ilmu Pengetahuan Alam, Universitas Negeri \\ Malang. Jalan Semarang 5 Malang, Indonesia \\ benyamintolonggeru2018@gmail.com
}

\begin{abstract}
The purpose of this study was to describe the critical thinking skills of class $\mathrm{X}$ high school students in solving SPLTV problems. This research was conducted in the even semester of 2020/2021. This type of research is descriptive research with a qualitative approach. Subjects in this study were 31 people from class X IPA1. The process of selecting subjects using the average value of daily tests. Data collection methods are critical thinking skills tests and interviews. The results showed that the ability of class X SMA students was in the low category with a percentage of $43.01 \%$. The ability to think critically for the interpretation aspect with a percentage of $38.71 \%$, the analytical aspect with a percentage of $58.06 \%$, the inference aspect with a percentage of $41.94 \%$, the explanation aspect of $9.68 \%$, and the aspect of self-regulation with a percentage of $48.39 \%$. low category while the evaluation aspect is in the medium category with a percentage of $61.29 \%$. For further researchers, it is necessary to examine the factors that affect the low ability of critical thinking at the high school level / equivalent. Keywords: Critical thinking skills, SPLTV
\end{abstract}

\begin{abstract}
Abstrak
Tujuan penelitian ini untuk mendeskripsikan kemampuan berpikir kritis siswa SMA kelas X dalam memecahkan masalah SPLTV. Penelitian ini dilakukan pada semester genap tahun 2020/2021. Jenis penelitian yang digunakan adalah penelitian deskripstif dengan pendekatan kualitatif. Subjek dalam penelitian ini ada 31 orang dari kelas $\mathrm{X}$ IPA1. Proses pemilihan subjek dengan menggunakan nilai rata-rata ulangan harian. Metode pengumpulan data adalah tes kemampuan berpikir kritis dan wawancara. Hasil penelitian bahwa kemampuan siswa kelas X SMA berada pada kategori rendah dengan persentase 43,01\%. Kemampuan berpikir kritis untuk aspek interpretasi dengan persentase $38,71 \%$, aspek analisis dengan persentase 58,06\%, aspek inferensi dengan persentase 41,94\%, aspek penjelasan 9,68\%, dan aspek regulasi diri dengan persentase 48,39\% berada pada kategori rendah sedangkan aspek evaluasi yang berada pada kategori sedang dengan persentase $61,29 \%$. Bagi peneliti selanjutnya, agar meneliti faktor-faktor yang mempengaruhi rendahnya kemampuan bepikir kritis pada jenjang SMA/sederajat.
\end{abstract}

Kata kunci: Kemampuan berpikir kritis, SPLTV

Copyright (c) 2021 Benyamin, Abd. Qohar, I Made Sulandra

$\triangle$ Corresponding author: Benyamin

Email Address: benyamintolonggeru2018@gmail.com (Jalan Mahameru VE 07/10 Tidar-Malang, Jawa Timur) Received 04 April 2021, Accepted 08 April 2021, Published 10 April 2021

\section{PENDAHULUAN}

Matematika adalah ibu dari segala ilmu pengetahuan yang mendasari suatu perkembangan aspek pengetahuan dan teknologi (Safitri, 2018). Lebih lanjut Risah \& Sutirna, (2019) mengatakan bahwa matematika adalah mata pelajaran yang bersifat logis dan kritis, maka matematika dijadikan mata pelajaran wajib disetiap jenjang agar dapat meningkatkan upaya dalam memajukan sumber daya manusia. Lebih lanjut Sholihah \& Afriansyah, (2017) mengatakan bahwa matematika mempunyai peranan yang sangat penting dan sebagai bekal pengetahuan bagi setiap orang dalam kehidupannya. Oleh sebab iu, matematika adalah ilmu pengetahuan yang bersifat logis yang wajib dipelajari oleh setiap orang untuk meningkatkan kualitas diri dalam kehidupannya.

Wahyudi \& Anugeraheni (2017) mengatakan bahwa pembelajaran adalah kegiatan yang sengaja 
yang dilakukan oleh guru dan siswa dalam situasi edukatif untuk mencapai tujuan yang diharapkan. Pembelajaran dapat dikatakan perubahan perilaku dan pengetahuan setiap seseorang sebagai hasil interaksi dengan lingkungan. Lebih lanjut Nazariah, Marwan, \& Abidin (2017) mengatakan bahwa pembelajaran matematika memberikan kontribusi terhadap pengembangan potensi akademik siswa dalam memecahkan persoalan matematika secara kreatif yang diberikan oleh guru.

Masalah matematika adalah suatu masalah dalam bentuk soal matematis yang harus dicari solusi yang tepat dan benar melalui prosedur pemecahan secara sistematis dan proses berpikir yang logis dalam memahami konsep maupun strategi yang digunakan (Indrawati, Muzaki, \& Febrilia, 2019). Masalah matematika yang dipecahkan harus sistematis dan prosedural. Lebih lanjut Akhiruddin, Sujarwo, Atmowardoyo, \& Nurhikmah, (2019) mengatakan bahwa agar siswa mampu menemukan pengetahuan baru, menciptakan gagasan yang hakiki dari materi pelajaran dan membentuk struktur intelektual maka harus diberikan persoalan yang kontekstual.

Pemecahan masalah adalah usaha yang dilakukan untuk memperoleh sebuah solusi dari persoalan yang dihadapi melalui kemampuan kognitif, keterampilan, dan pemahaman yang dimiliki sebelumnya (Hidayat, Sa'dijah, \& Sulandra, 2019). Lebih lanjut Christiyanto, Sulandra, \& Rahardi, (2018) mengatakan bahwa pemecahan masalah adalah suatu proses kemampuan kognitif dengan cara menganalisis, menjelaskan, bernalar, memprediksi, mempertimbangkan dan melakukan introspeksi diri dengan melibatkan kemampuan beprikir kritis untuk menyelesaikan persoalan non rutin melalui strategi yang tepat dan benar. Sejalan dengan hal tersebut Rahman (2019) menjelaskan bahwa pemecahan masalah adalah proses melibatkan pengamatan sistematis dan berpikir kritis untuk menemukan penyelesaian yang tepat demi mencapai tujuan yang diinginkan. Dengan adanya kemampuan pemecahan masalah yang baik maka akan dapat meningkatkan kemampuan berpikir kritis.

Hedges (1996) menjelaskan bahwa kemampuan berpikir kritis adalah kemampuan dasar untuk memecahkan masalah dan pengambilan keputusan yang tepat. Lanjutnya kemampuan berpikir kritis yaitu: (1) Kemampuan untuk mengidentifikasi, merumuskan dan menyelesaikan permasalahan; Kemampuan untuk mengenali kekeliruan dan menggunakan penalaran induktif; (2) Kemampuan untuk menarik kesimpulan yang logis dari keterangan yang diperoleh berdasarkan sumber tertulis, lisan, diagram, atau grafik dan mempertanggungjawabkan kesimpulan yang telah diambil; (3) Kemampuan untuk menginterpretasi, mengembangkan, dan menggunakan ide; dan (4) Kemampuan untuk membedakan antara fakta dengan pendapat.

Berpikir kritis adalah kemampuan yang digunakan untuk menyelesaikan persoalan hidup dengan melibatkan penalaran yang masuk akal, menafsirkan, menganalisis dan mengevaluasi segala bentuk informasi sehingga seseorang dapat dipercaya dalam mengambil keputusan yang sah (Chukwuyenum, 2013). Demikian dipertegas oleh Hidayat \& Sari (2019) bahwa untuk memecahkan persoalah hidup sehari-hari perlu adanya kemampuan berpikir kritis. Lebih lanjut Atabaki, Keshtiaray, \& Yarmohammadian (2015) mengatakan bahwa setiap orang memerlukan kemampuan berpikir kritis agar sukses memecahkan masalah dalam situasi yang sulit dan selalu memiliki hubungan yang efektif dan 
baik dengan siapapun. Lebih lanjut bahwa berpikir kritis adalah kemampuan sangat penting yang dikenal secara luas untuk penilaian dan pengaturan diri (Abrami et al., 2008).

Berpikir kritis adalah salah satu dari aspek empat keterampilan yang dibutuhkan (Basri, Purwanto, As'ari., \& Sisworo, 2019) dan suatu model yang sebagai atribut sangat penting untuk dimiliki oleh siswa agar lebih sukses di abad ke - 21 ( ŽivkoviL, 2016; Wulandari, Amin, Zubaidah, \& IAM, 2017; Elisanti, Sajidan, \& Prayitno, 2018). Dengan hal tersebut, maka kemampuan berpikir kritis itu penting untuk membantu siswa agar memiliki pandangan kritis tentang masalah dan mengatasi permasalahan yang terjadi (Atabaki et al., 2015); dan membantu untuk memecahkan persoalan dan pengambilan keputusan yang tepat sesuai dengan tujuan yang diinginkan (Tosuncuoglu, 2018).

Berdasarkan hasil observasi dan hasil wawancara dengan guru mata pelajaran matematika di SMAS St. Thomas Aquinas diperoleh bahwa masih sebagian besar siswa memperoleh nilai ulangan harian dibawah KKM 75 dari setiap kelas yang disebabkan karena siswa mengalami kesulitan dalam mengerjakan soal cerita matematika yang diberikan oleh guru yaitu tidak membuat pemisalan dari pernyataan soal dengan benar, tidak mampu membuat model matematika, dan belum mampu menyelesaikan soal dengan benar. Soal ulangan yang diberikan yakni soal cerita bentuk kontekstual yang bertujuan untuk melihat capaian tujuan pembelajaran dan indikator yang telah dibuat berdasarkan kompetensi dasar sesuai kurikulum 2013.

Sistem persamaan linear tiga variabel (SPLTV) adalah materi yang wajib yang dipelajari oleh siswa kelas X SMA. Metode penyelesaian SPLTV yaitu metode eliminasi, metode substitusi dan metode determinan (aturan cramer) (Sukino, 2014; Noormandiri, 2016). Materi SPLTV suatu peralihan dari materi SPLDV yang telah dipelajari oleh siswa pada jenjang SMP. Dengan memahami materi SPLDV maka siswa dapat memami SPLTV. Hal ini sejalan dengan pendapat Zakiyah, Hidayat, \& Setiawan, (2019) yang mengatakan bahwa siswa dengan latar belakang memahami materi SPLDV yang baik maka siswa tersebut lebih cenderung mudah memahami SPLTV dengan baik pula. Namun, nateri SPLTV masih menjadi hal yang sulit bagi karena proses menyelesaikan panjang, ribet dan membutuhkan waktu yang lama.

Hasil penelitian dilakukan oleh Basri et al., (2019) yaitu: (1) Tingkat kemampuan berpikir kritis siswa berada pada kriteria rendah; (2) Sub kemampuan berpikir kritis yaitu: Analisis, evaluasi, inferensi, penjelasan, dan pengaturan diri berada pada kategori rendah dibandingkan dengan interpretasi yang berada pada kriteria sedang. Lebih lanjut hasil penenlitian yang dilakukan oleh Riskiyah, Jannah, \& Aini, (2018) bahwa ketiga subjek penelitian memiliki kemampuan berpikir kritis berbeda satu sama lain dalam menyelesaikan masalah soal cerita materi fungsi kuadrat, namun ketiga subjek tersebut mampu mencapai semua aspek berpikir kritis yaitu: interpretasi, analisis, evaluasi, inferensi, penjelasan, dan regulasi diri.

Berdasarkan hal di atas penelitian ini perlu dilakukan yang hasilnya sebagai acuan bagi tenaga pendidikan dalam pembelajaran. Oleh karena itu, tujuan penelitian ini adalah untuk mendeskripsikan kemampuan berpikir kritis siswa SMA kelas X dalam memecahkan masalah SPLTV. 


\section{METODE}

Lokasi penelitian ini di SMA St. Thomas Aquinas, Jalan Bukit Sunyi, Kecamatan Kota Tambolaka, Kabupaten Sumba Barat Daya, Nusa Tenggara Timur. Jenis penelitian yang digunakan adalah deskriptif dengan pendekatan kualitaif. Penelitian dilaksanakan di kelas X SMA pada tahun pelajaran 2020/2021. Subjek dalam penelitian ini adalah siswa kelas X IPA 1. Subjek dipilih berdasarkan rata-rata nilai ulangan harian. Setelah memperoleh subjek maka selanjutnya diberikan lembar tes kamampuan berpikir kritis. Penelitian ini menggunakan indikator yang telah dikembangkan dari komponen inti aspek kemampuan berpikir yang dikemukkan oleh Facione (2015) yaitu: (1) interpretasi, (2) analisis, (3) evaluasi, (4) inferensi, (5) penjelasan, dan (6) regulasi diri.

Tabel 1. Indikator Kemampuan Berpikir Kritis

\begin{tabular}{|l|l|}
\hline \multicolumn{1}{|c|}{ Aspek Berpikir Kritis } & \multicolumn{1}{c|}{ Indikator } \\
\hline Interpretasi & $\begin{array}{l}\text { 1. Siswa mampu menuliskan yang diketahui } \\
\text { 2. Siswa mampu menuliskan ditanyakan } \\
\text { 3. Siswa mampu melakukan pemodelan matematika dengan } \\
\text { tepat dan benar }\end{array}$ \\
\hline Analisis & $\begin{array}{l}\text { Siswa mampu menentukan informasi yang penting, tepat dalam } \\
\text { memilih metode penyelesaian, dan melakukan perhitungan } \\
\text { dengan tepat dan benar }\end{array}$ \\
\hline Evaluasi & $\begin{array}{l}\text { 1. Siswa mampu menuliskan penyelesaian soal dengan tepat } \\
\text { dan benar } \\
\text { 2. Siswa mampu menggunakan alternatif jawaban yang lain }\end{array}$ \\
\hline Inferensi (Kesimpulan) & $\begin{array}{l}\text { Siswa mampu menarik kesimpulan dari permasalahan yang } \\
\text { diberikan }\end{array}$ \\
\hline Penjelasan & $\begin{array}{l}\text { Siswa mampu menuliskan hasil akhir yang benar dan tepat, } \\
\text { serta memberikan alasan dalam bentuk argumen yang } \\
\text { meyakinkan }\end{array}$ \\
\hline Regulasi Diri & $\begin{array}{l}\text { Siswa mampu melakukan pengecekan ulang hasil penyelesaian } \\
\text { soal dengan tepat dan benar }\end{array}$ \\
\hline
\end{tabular}

Prosedur penelitian ini, yaitu : 1) Mengumpulkan nilai ulangan harian dari guru mata pelajaran, 2) Mencari rata-rata dari nilai ulangan harian, 3) pemilihan subjek penelitian, 3) subjek yang dipilih dipertimbangkan lagi dengan mengonsultasikan dengan guru mata pelajaran matematika, 4) peneliti memberikan tes kemampuan berpikir kritis, 5) peneliti melakukan wawancara secara acak berdarsarkan hasil tes, dan 6) menyimpulkan hasil penelitian.

Instrumen pengumpulan data terdiri dari instumen utama dan instrumen pendukung. Instrumen utama dalam penelitian ini adalah peneliti terlibat langsung untuk mengumpulkan data dari subjek penelitian sebagai sumber data. Instrumen pendukung yaitu (1) Lembar tes kemampuan berpikir kritis, bertujuan untuk mengukur ketercapaian siswa dalam menyelesaikan masalah SPLTV kemudian menganalisis untuk mendeskripsikan kemampuan berpikir kritis siswa, (2) Pedoman wawancara, bertujuan mewawancarai subjek yang berkaitan dengan hasil pekerjaan yang telah dilakukan oleh subjek dalam menyelesaikan permasalahan yang diberikan, dan (3) Alat bantu rekam, untuk merekam kegiatan peneliti dengan subjek saat wawancara. 
Analisis data dalam penelitian ini mengacu pada analisis data kualitatif menurut Miles dan Huberman (Sugiyono, 2013) yaitu tahap reduksi data, pada penelitian ini peneliti melakukan reduksi data dimulai dari hasil tes kemampuan berpikir kritis sampai pada hasil wawancara. Tahap Penyajian data, data disajikan dalam bentuk tabel atau grafik yang menggambarkan hasil penelitian. Tahap penyimpulan data, menyimpulkan hasil penelitian terkait berpikir kritis siswa dalam memecahkan masalah SPLTV.

\section{HASIL DAN DISKUSI}

Subjek penelitian dalam ini terdiri dari 31 orang yang menunjukkan bahwa ada 10 orang berada pada kategori tinggi, ada 8 orang yang berada pada kategori sedang dan ada 14 orang berada pada kategori rendah. Secara jelas dapat di lihat pada grafik 1.

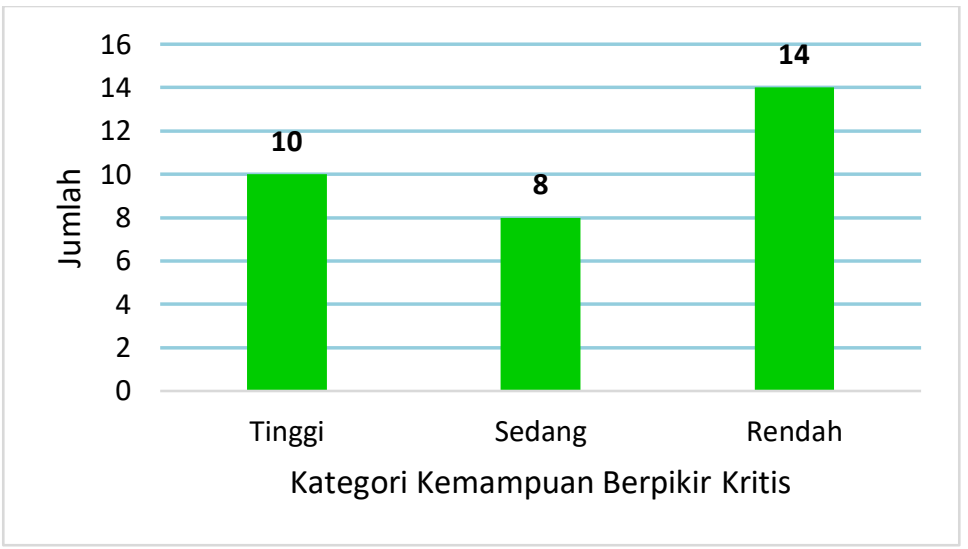

Grafik 1. Rekapitulasi subjek yang berada pada setiap kategori kemampuan berpikir kritis

Ketercapaian subjek yang berjumlah 31 orang berdasarkan aspek kemampuan berpikir kritis adalah sebagai berikut:

\section{Aspek Interprestasi}

Pada aspek interprestasi ada 12 orang subjek atau tingkat persentase $38,71 \%$ dari jumlah 31 subjek yang mampu menjawab benar.

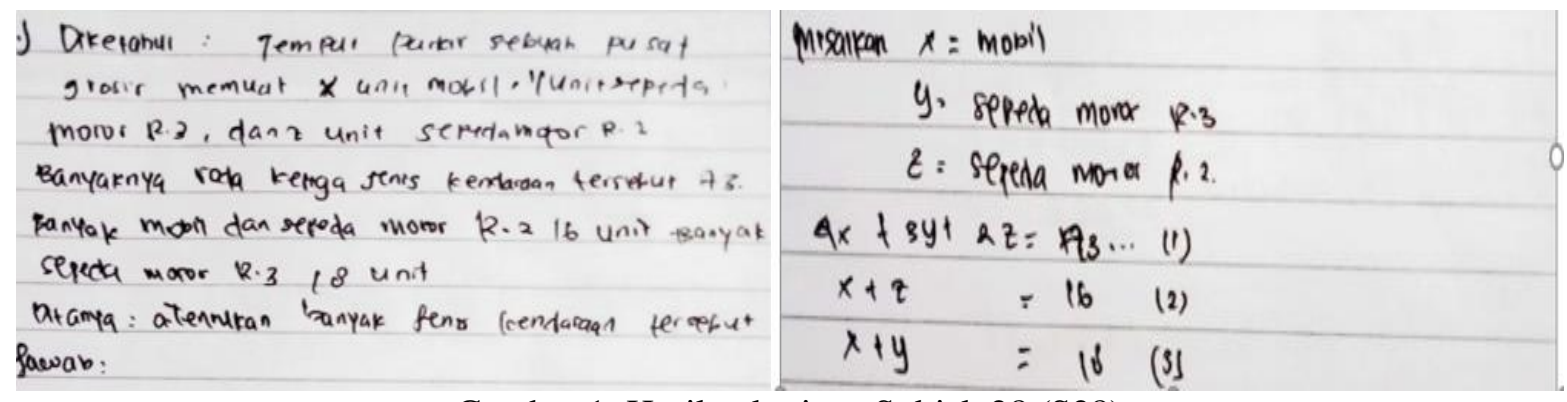

Gambar 1. Hasil pekerjaan Subjek 28 (S28)

Berikut cuplikan hasil wawancara dengan S28:

Peneliti : mengapa adik menuliskan ulang soal adalah bagian dari diketahui? 
S28

: Tidak pak. itu bagian diketahui pak

Peneliti : Apakah menurut adik bahwa pemisalan dan model matematika bagian dari diketahui dan bagian jawaban?

S28 : bagian di jawaban pak

Peneliti : menurutmu bagaimana urutan dalam mengerjakan soal yang benar?

S28 : tulis yang diketahui, ditanyakan kemudian dijawab pak

Peneliti : Lalu apa menjadi jawaban yang adik kerjakan tersebut?

S28 : model matematikanya pak

Peneliti : Apakah adik menuliskan model matematika dengan benar?

S28 : menurut saya sudah pak

Peneliti : Menurut adik apa hubungan yang diketahui dengan yang ditanyakan?

S28 : menurut saya dengan diketahui bisa menjadi dasar untuk memperoleh apa yang ditanyakan pak.

Berdasarkan hasil wawawancara dapat disimpulkan bahwa S28 menuliskan ulang soal sebagai yang diketahui karena pada soal terdapat pemisalan $x, y$, dan $z$. Kesalahan ini atas dasar belum memahami untuk menentukan yang diketahui dari soal yang diberikan. Namun, S28 benar menyatakan model matematika dengan benar dari soal dan dapat mengetahui hubungan dari yang diketahui dengan ditanyakan.

\section{Aspek Analisis}

Pada aspek analisis ada 18 orang subjek atau 58,06\% yang mampu menjawab benar dari jumlah 31 subjek.

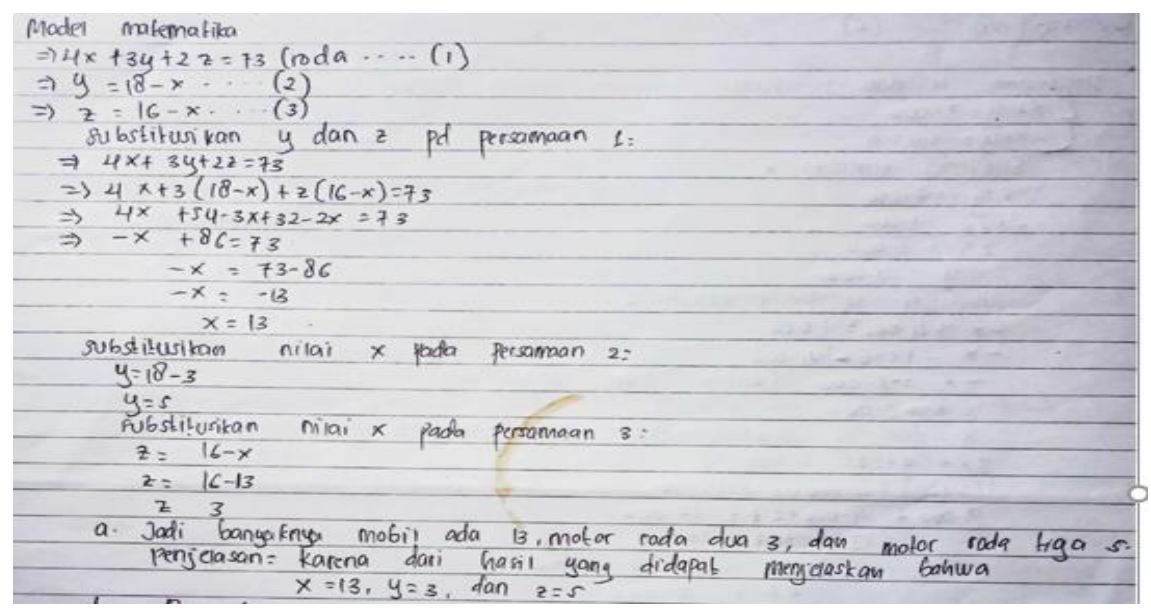

Gambar 2. Hasil pekerjaan Subjek 8 (S8)

Berikut cuplikan hasil wawancara dengan S8:

Peneliti : apa yang adik lakukan terhadap soal tersebut?

S8 : saya mencermti soal dengan baik, kemudian saya menuliskan pemisalan, yang diketahui, dan ditanyakan. Lalu saya menyelesuaikan dengan metode penyelesaian SPLTV pak

Peneliti : Metode apa yang anda gunakan dalam penyelesaian tersebut? 
S8 : metode substitusi pak

Peneliti : Bagaimana cara adik memilih metode penyelesaian?

S8 : Saya melihat model SPL nya pak

Peneliti : Mengapa?

S8 : Karena lebih cocok

Peneliti : Apa maksud adik $\mathrm{y}=18-\mathrm{x} \ldots(2)$ dan $\mathrm{z}=16-\mathrm{x}$ ?

S8 : Maksudnya pak bahwa $\mathrm{y}=18-\mathrm{x} \ldots$ (2) telah dirubah dari $\mathrm{x}+\mathrm{y}=18$ dan $\mathrm{z}=16-\mathrm{x} \ldots$ (3) dari $x+z=16$ ?

Peneliti : mengapa?

S8 $\quad$ : agar lebih mudah disubstitusi pak untuk memperoleh nilai variabel pak

Peneliti : Apakah hasil yang dikerjakan menurutmu sudah benar dan tepat

S8 : sudah pak. setelah saya melakukan pengecekan kembali hasilnya sama pak pada persamaan

Berdasarkan hasil wawancara disimpulkan bahwa S8 mencermati soal dengan baik, membuat pemisalan, membuat model matematika, dan tepat mencocokan metode substitusi sebagai metode yang sederhana dalam menyelesaikan soal tersebut. Dalam menyelesaikan soal ini kalaupun menggunakan metode selain substitusi maka harus teliti melihat variabel mana yang harus dieliminasikan karena tidak semua variabel dalam dari persamaan ini tepat dieliminasikan. Maka dari itu S8 mampu meneganlisis soal terlebih dahulu dan mampu menggunakan metode substitusi sebagai cara terbaik menyelesaikan soal sehingga memperoleh jawaban yang benar.

\section{Aspek Evaluasi}

Pada aspek evaluasi ada 19 orang subjek atau 61,29\% yang mampu menjawab benar dari jumlah 31 subjek.



Gambar 3. Hasil pekerjaan Subjek 15 (S15)

Berikut cuplikan hasil wawancara dengan S15:

Peneliti : Metode apa yang adik gunakan untuk menyelesaikan soal $1 \mathrm{~b}$ ?

S15 : Metode Substitusi pak

Peneliti : Apakah adik bisa menyelesaikan soal dengan metode substitus?

S15 : Bisa pak

Peneliti : Oh ia, apakah maksud adik bahwa $-2 \mathrm{y}=-8.000$ menjadi $\mathrm{y}=-8.000 / 2$ sehingga $\mathrm{y}=4.000$ ?

S15 : Baik pak. Maksudnya bahwa kedua ruas dibagi -2 pak

Peneliti : Lalu adik merasa bahwa pekerjaannya sudah tepat dan benar? 
S15 : sudah pak

Peneliti : coba lihat dulu poses penyelesaian dengan seksama

S15 : baik pak

Peneliti : Bagaimana?sudah benar?

S15 : Eh ia pak. saya lupa menulisnya tanda (-) pada $y=-8.000 / 2$ pak seharusnya $y=-8.000 /-$ 2 sehingga $\mathrm{y}=4.000$

Berdasarkan hasil wawawancara dapat disimpulkan bahwa S15 mampu menyelesaikan soal dengan cara lain yakni cara substitusi selain yang digunakan pada penyelesaian soal sebelumnya. Namun, S15 menyadari bahwa tidak teliti dalam menuliskan tanda pada pembagian kedua ruas untuk menentukan nilai $y$ yang walaupun hasil akhirnya benar. Dengan ketidaktelitian ini ditegaskan bahwa sebuah tanda itu sangat berarti dalam menentukan hasil selanjutnya pada penyelesaian soal matematika.

\section{Aspek Inferensi}

Pada aspek inferensi ada 13 subjek atau 41,94\% yang mampu menjawab benar dari jumlah 31 subjek

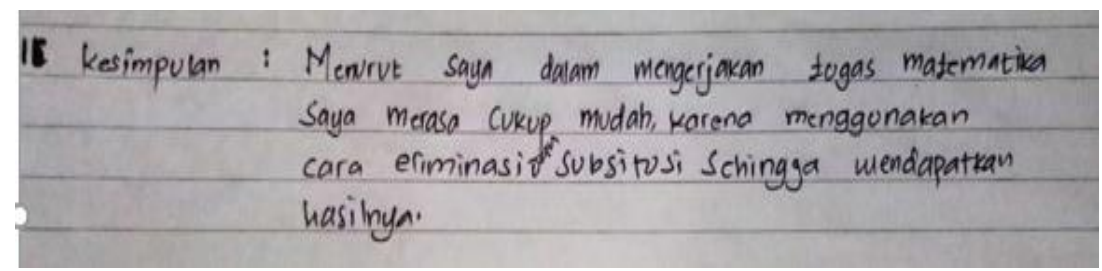

Gambar 4. Hasil pekerjaan Subjek 1 (S1)

Berikut cuplikan hasil wawancara dengan S1:

Peneliti : Apa maksud soal 1c?

S1 : Berilah kesimpulan berdasarkan hasil penyelesaian cara pertama dengan cara kedua yang telah dikemukakan pak

Peneliti : Apakah adik paham tentang soal tersebut?

S1 : Paham pak

Peneliti : Lalu mengapa adik memberikan kesimpulan seperti ini?apa maksudnya?

S1 : saya bermaksud bahwa soal yang diberikan mudah dikerjakan dengan menggunakan metode eliminasi dan substitusi pak

Peneliti : Bagaimana hasil yang diperoleh adik dengan cara eliminasi dan susbtitusi?

S1 : hasilnya Sama pak

Peneliti : lalu bagaimana kesimpulannya yang tepat?

S1 : Kesimpulannnya dengan cara berbeda tapi hasilnya sama pak

Berdasarkan hasil wawancara dapat disimpulkan bahwa awalnya S1 belum mampu membuat kesimpulan dari pernyataan dengan benar dan tepat karena S1 hanya melihat dari sisi kemudahan menyelesaikan soal dengan metode eliminasi dan substitusi yang telah dikerjakan. Di lain hal, S1 tidak melihat bahwa yang dihasilkan itu suatu pernyataan yang menjadi dasar untuk membuat kesimpulan. Namun, setelah S1 ditanya lebih jauh tentang hasil yang duperoleh dengan metode eliminasi dan 
substitusi maka S1 dapat memahami sehingga mampu memberikan kesimpulan yang benar.

\section{Aspek Penjelasan}

Pada aspek penjelasan ada 3 atau 9,68\% subjek yang mampu menjawab soal sesuai dengan indikator dari jumlah 31 subjek. Pada aspek ini ada 28 subjek yang belum mampu memberikan penjelasan (alasan) dan tidak mengerjakan sama sekali terkait jawaban yang diperoleh karena tidak terbiasa dengan soal seperti ini.

\section{Aspek Regulasi Diri}

Pada aspek regulasi diri ada 15 subjek atau 48,39\% yang mampu menjawab soal sesuai dengan benar dari jumlah 31 orang.



Gambar 5. Hasil pekerjaan Subjek 11 (S11)

Berikut cuplikan hasil wawancara dengan S11:

Peneliti : Apa maksud adik menuliskan pengecekan?

S11 : saya bermaksud untuk melakukan pengecekan jawaban yang diperoleh pak

Peneliti : apa yang adik lakukan?

S11 : saya melakukan pengecekan dengan mengambil nilai dari variabel yang diperoleh kemudian disubstitusi pada persamaan pak

Peneliti : Apa maksud adik menuliskan $52+6+15=173$ roda jenis kendaraan?

S11 : maaf pak, itu bukan 173 tapi 73 pak

Peneliti : apakah maksud anda menuliskan seperti itu?

S11 : ruas kiri itu dijumlahkan pak sehingga menghasilkan 73 sehingga sama dengan sebelah kanan 73 pak

Peneliti : mengapa adik tidak mengecek ke semua persamaan yang ada?

S11 : saya berpikir hanya satu persamaan pak

Peneliti : bisa kah adik membuktikannya lagi ke persamaan lain?Buktikan

S11 : Bisa pak.

Berdasarkan hasil wawancara, S11 menuliskan pengecekan kembali terhadap jawaban yang diperoleh pada persamaan 1 yang walaupun S11 ini tidak menyadari hasil yang seharusnya 73 tetapi ditulis 173. Namun, setelah ditanya maka S11 menyatakan bahwa 73. Setelah disuruh melakukan pengecekan kembali pada persamaan yang lain maka S11 dapat membuktikan dengan baik dan benar sesuai hasil yang diperoleh pada bentuk SPLTV dalam bentuk model matematika.

Berdasarkan hasil penelitian maka hasil tersebut dapat direkapitulasi persentase siswa 
berdasarkan setiap aspek kemampuan berpikir kritis yang dapat dilihat pada grafik 2 .

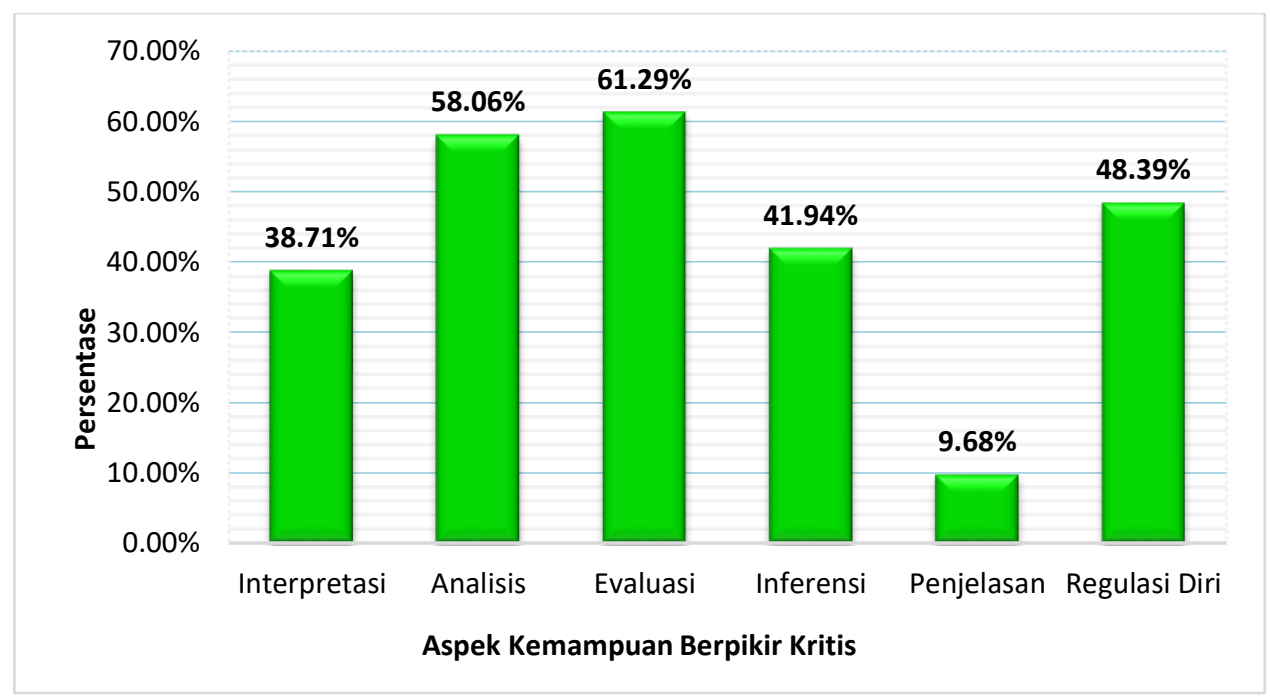

Grafik 2. Rekapitulasi persentase siswa berdasarkan aspek kemampuan berpikir kritis

Berdasarkan hasil penelitian bahwa kemampuan berpikir kritis siswa SMA Kelas X SMAS St. Thomas Aquinas berada pada kategori rendah dengan persentase $43,01 \%$ yang diperoleh dari hasil ratarata tiap aspek berpikir kritis. Hal ini karena capaian siswa berbeda-beda setiap aspek kemampuan berpikir kritis. Sejalan dengan pendapat Nuryanti, Zubaidah, \& Diantoro (2018) yang menyatakan kategori jawaban kemampuan berpikir kritis siswa tiap aspek bervariasi.

Facione (1990) menjelaskan bahwa interpretasi: untuk menafsirkan dan menyatakan pengertian, kondisi, data, peristiwa, penilaian, kaidah-kaidah, kepercayaan, norma-norma, metode atau kategori. Lebih lanjut menjelaskan Sharadgah, Sa'di, \& Ahmad, (2019) bahwa aspek yang pertama dinilai adalah interpretasi. Pada aspek ini siswa berada tergolong rendah dengan persentase $38,71 \%$. Berdasarkan hasil wawancara bahwa siswa menganggap bahwa soal itu yang menjadi diketahui, namun model matematika yang buat adalah benar.

Aspek analisis adalah aspek kedua menurut Facione. Facione (2013) menjelaskan: untuk mengenali suatu hubungan kesimpulan yang diharapkan dan aktual dari pernyataan, pertanyaan, konsep, gambaran demi menyatakan suatu kepercayaan, penilaian, pengalaman, alasan, dan informasi. Pada aspek ini siswa tergolong rendah dengan persentase $58,06 \%$. Berdasarkan hasil wawancara siswa memilih metode substitusi yang lebih cocok untuk menyelesaikan soal SPL yang diberikan sehingga memperoleh hasil yang sesuai harapan indikator.

Aspek Evaluasi adalah aspek ketiga menurut Facione. Facione (2013) menjelaskan bahwa evaluasi: untuk menilai kredibilitas pernyataan, pengetahuan, kondisi, penilaian, keyakinan, atau pendapat seseorang; dan untuk menilai hubungan kesimpulan yang aktual antara pernyataan, gambaran, pertanyaan, atau bentuk representasi yang masuk akal. Aspek ini tergolong sedang dengan persentase $61,29 \%$. Berdasarkan hasil wawancara siswa mampu menyelesaikan cara lain selain yang telah digunakan sebelumnya yang walapun dalam proses penyelesain siswa tidak teliti. Siswa menyadari 
kekeliruannya setelah proses wawancara namun mampu mengungkapkan jawaban yang benar.

Aspek inferensi adalah aspek keempat menurut Facione. Facione (2013) menjelaskan bahwa evaluasi: untuk mengidentifikasi dan mempersetasikan bagian penting untuk mengambil kesimpulan yang logis; untuk membuat asumsi dan hipotesis; untuk mempertimbangkan keterangan yang relevan dan mengembangkan hal penting dari suatu data, pernyataan, hukum, bukti, penilaian, kepercayaan, pendapat, bentuka rancangan, gambaran, dan pertanyaan. Lebih lanjut menurut Indrawatiningsih et al., (2019) inferensi adalah kemampuan yang dimiliki oleh siswa untuk menarik sebuah kesimpulan berdasarkan pernyataan. Pada aspek ini siswa tergolong rendah dengan persentase 41,94\%. Berdasarkam hasil wawancara siswa bisa memberikan kesimpulan yang benar berdasarkan yang telah dikerjakan.

Aspek penjelasan adalah aspek kelima menurut Facione. Facione (2015) menjelaskan bahwa seseorang mampu menyajikan dengan cara yang meyakinkan dan koheren hasil dari penalaran. Aspek ini berada pada kategori rendah dengan persentase 9,68\%. Aspek ini paling rendah dari aspek lain karena siswa tidak mampu memberikan alasan (penjelasan) dan tidak menuliskan alasan berdasarkan yang telah dikerjakan.

Aspek regulasi diri adalah aspek keenam menurut Facione. Facione (2015) mendefinisikan regulasi diri adalah usaha secara sadar melihat kembali kegiatan kognitif seseorang, hal-hal yang digunakan dalam kegiatan tersebut, dan menganalisis hasil yang diperoleh berdasarkan penerapan keterampilan, dan mengevaluasi terhadap kesimpulan seseorang dengan tujuan mempertanyakan, mengkonfirmasi, meverifikasi, atau mengecek kembali alasan seseorang. Pada aspek ini siswa tergolong rendah yang berada dengan persentase $48,39 \%$. Berdasarkan hasil wawancara bahwa siswa mampu melakukan pengecekan kembali terhadap jawaban yang diperoleh.

Melalui hasil penelitian ini maka tenaga pendidik perlu memperhatikan secara serius tentang perkembangan kemampuan berpikir kritis siswa. Sejalan dengan pendapat Aghababaeian, Moghaddam, Nateghi, \& Faghihi (2017) bahwa dengan mengembangkan kurikulum sesuai pembelajaran dalam sistem pendidikan maka dapat menjadi salah cara untuk men capai dan mengembangkan kemampuan berpikir kritis siswa. Dengan demikian sejalan dengan pendapat Irawan, Rahardjo, \& Sarwanto, (2017) bahwa guru harus berkompeten dalam memilih, merancang, mengembangkan pembelajaran dan memfasilitasi siswa untuk berlatih berpikir kritis

\section{KESIMPULAN}

Berdasarkan hasil penelitian dapat disimpulkan bahwa kemampuan berpikir kritis siswa SMA kelas X St. Thomas Aquinas berada pada kategori rendah. Kemampuan berpikir kritis berdasarkan aspek interpretasi, aspek analisis, aspek inferensi, aspek penjelasan dan aspek regulasi diri berada pada kategori rendah sedangkan aspek evaluasi berada pada kategori sedang.

Berdarsarkan hal tersebut bahwa tenaga pendidik (guru) perlu mengembangkan model pembelajaran untuk meningkatkan kemampuan berpikir kritis siswa, serta guru perlu selalu memberikan soal-soal 
yang menggambarkan kemampuan berpikir kritis siswa yang dengan hal tersebut dapat membiasakan siswa untuk meningkat kemampuan berpikir kritis. Disamping hal tersebut, bagi peneliti selanjutnya agar meneliti faktor-faktor yang mempengaruhi rendahnya kemampuan berpikir kritis siswa.

\section{UCAPAN TERIMA KASIH}

Saya mengucapkan limpahan terima kasih kepada kepada Frater M. Polikarpus, BHK. S.E., M. Pd Selaku ketua Yayasan Mardi Wiyata yang telah mendanai dan mengucapkan limpahan terima kasih kepada Kepala Sekolah serta guru - guru SMAS St. Thomas Aquinas, Sumba Barat Daya, Provinsi Nusa Tenggara Barat yang telah memberikan ruang dan waktu untuk penelitian artikel ini.

\section{REFERENSI}

Abrami, P. C., Bernard, R. M., Borokhovski, E., Wade, A., Surkes, M. A., Tamim, R., \& Zhang, D. (2008). Instructional interventions affecting critical thinking skills and dispositions: A stage 1 Meta-Analysis. Review of Educational Research, 78(4), 1102-1134. https://doi.org/10.3102/0034654308326084

Aghababaeian, P., Moghaddam, S. A. H., Nateghi, F., \& Faghihi, A. (2017). Investigating Changing In Social Studies Textbooks of Public Review (Basic Fourth and Fifth) Based on the Emphasis on Critical Thinking Skills Facione in the Last Three Decades. International Education Studies, 10(3), 108-115. https://doi.org/10.5539/ies.v10n3p108

Akhiruddin, Sujarwo, Atmowardoyo, H., \& Nurhikmah. (2019). Belajar dan Pembelajaran (Cetakan Pertama). Maka: CV. Cahaya bintang Cemerlang.

Atabaki, A. M. S., Keshtiaray, N., \& Yarmohammadian, M. H. (2015). Scrutiny of Critical Thinking Concept. International Education Studies, 8(3), 93-102. https://doi.org/10.5539/ies.v8n3p93

Basri, H., Purwanto, As'ari., A. R., \& Sisworo. (2019). Investigating Critical Thinking Skill of Junior High School in Solving Mathematical Problem. International Journal of Instruction, 12(3), 745758. https://doi.org/10.29333/iji.2019.12345a

Christiyanto, D. Y., Sulandra, I. M., \& Rahardi, R. (2018). Proses Berpikir Kritis Siswa Reflektif dalam Menyelesaikan Masalah Matematika pada Materi Sistem Persamaan Linier Dua Variabel. Jurnal Pendidikan, 3(10), 1347-1358.

Chukwuyenum, A. N. (2013). Impact of critical thinking on performance in mathematic. IOSR Journal of Research \& Method in Education, 3(5), 18-25. Retrieved from www.iosrjournals.orgwww.iosrjournals.org 18\%7C\%0Awww.iosrjournals.org

Elisanti, E., Sajidan, \& Prayitno, B. A. (2018). The Profile of Critical Thinking Skill Students in XI Grade of Senior High School. Advances in Social Science, Education and Humanities Research, 218(January). Retrieved from http://creativecommons.org/licenses/by-nc/4.0/)

Facione, P. A. (1990). Critical Thinking: A Statement of Expert Consensus for Purposes of Educational Assessment and Instruction. Research Findings and Recommendations. California States 
University, Fullerton.

Facione, P. A. (2013). Critical Thinking: What It Is and Why It Counts. 1-28.

Facione, P. A. (2015). Critical Thinking: What It Is and Why It Counts. In Insight assessment. Retrieved from https://www.insightassessment.com/CT-Resources/Teaching-For-and-About-CriticalThinking/Critical-Thinking-What-It-Is-and-Why-It-Counts/Critical-Thinking-What-It-Is-andWhy-It-Counts-PDF

Hedges, L. E. (1996). Teaching for Connection: Critical Thinking Skills, Problem Solving, and Academic and Occupational Competencies (Columbus). Associate Professor Emeritus Department of Agricultural Education The Ohio State University.

Hidayat, A., Sa'dijah, C., \& Sulandra, I. M. (2019). Proses Berpikir Siswa Field Dependent dalam Menyelesaikan Masalah Geometri Berdasarkan Tahapan Polya. Jurnal Pendidikan: Teori, Penelitian, Dan Pengembangan, 4(7), 923-937.

Hidayat, W., \& Sari, V. T. A. (2019). Kemampuan Berpikir Kritis Matematis dan Adversity Quotient Siswa SMP. Jurnal Elemen, 5(2), 242. https://doi.org/10.29408/jel.v5i2.1454

Indrawati, K. A. D., Muzaki, A., \& Febrilia, B. R. A. (2019). Profil Berpikir Siswa dalam Menyelesaikan Soal Sistem Persamaan Linear. Jurnal Didaktik Matematika, 68-83. https://doi.org/10.24815/jdm.v6i1.12200

Indrawatiningsih, N., Purwanto, As'Ari, A. R., Dwiyana, Sudirman, \& Rahardi, R. (2019). The ability of high school students' critical thinking in solving trigonometric problems. IOP Conference Series: Earth and Environmental Science, 243(1). https://doi.org/10.1088/17551315/243/1/012050

Irawan, T. A., Rahardjo, S. B., \& Sarwanto. (2017). Analisis Kemampuan Berpikir Kritis Siswa Kelas VII-A SMP Negeri 1 Jaten. Prosiding Seminar Nasional Pendidikan Sains (SNPS), 232-236. Retrieved from http://www.jurnal.fkip.uns.ac.id/index.php/snps/article/viewFile/11418/8103

Nazariah, Marwan, \& Abidin, Z. (2017). Intuisi Siswa SMK dalam Memecahkan Masalah Matematika Ditinjau dari Kemampuan Matematika dan. Jurnal Didaktik Matematika, 4185(1), 35-52.

Noormandiri, B. K. (2016). Matematika untuk SMA/MA Kelas X Kelompok Wajib Kurikulum 2013 (Edisi Revi; Taryo, M. Darmnto, \& B. Sutrisno, eds.). Jakarta: Penerbit Erlangga.

Nuryanti, L., Zubaidah, S., \& Diantoro, M. (2018). Analisis Kemampuan Berpikir Kritis Siswa SMP. Jurnal Pendidikan, 3(2), 155-158.

Rahman, M. M. (2019). 21st Century Skill "Problem Solving": Defining the Concept. Asian Journal of Interdisciplinary Research, 2(1), 71-81.

Risah, Y., \& Sutirna. (2019). Analisis kemampuan berpikir kritis siswa pada materi koloid. Prosiding Seminar Nasional Matematika Dan Pendidikan Matematika Sesiomadika. Retrieved from http://journal.unsika.ac.id/index.php/sesiomadika

Riskiyah, S., Jannah, U. R., \& Aini, S. D. (2018). Analisis Kemampuan Berpikir Kritis Siswa SMA Berkemampuan Matematika Tinggi dalam Menyelesaikan Masalah Fungsi. Jurnal Tadris 
Matematika, 1(2). https://doi.org/10.21274/jtm.2018.1.2.111-122

Safitri, H. A. (2018). Profil Berpikir Kritis Siswa dalam Memecahkan Masalah HOT Ditinjau dari Kemampuan Matematika. MATHEdunesa Jurnal Ilmiah Pendidikan Matematika, 1, 32-39.

Sharadgah, T. A., Sa'di, R. A., \& Ahmad, H. H. (2019). Promoting and Assessing EFL College Students' Critical Thinking Skills through Argumentative Essay Writing. Arab World English Journal, 10(4), 133-150. https://doi.org/10.24093/awej/vol10no4.11

Sholihah, S. Z., \& Afriansyah, E. A. (2017). Analisis Kesulitan Siswa dalam Proses Pemecahan Masalah Geometri Berdasarkan Tahapan Berpikir Van Hiele. Mosharafa: Jurnal Pendidikan Matematika, 6(2), 287-298. https://doi.org/10.31980/mosharafa.v6i2.317

Sugiyono. (2013). Metode Penelitian Pendidikan Pendekatan Kuantitatif, Kualitatif, dan R\&D. Bandung: Alfabeta.

Sukino. (2014). Matematika untuk SMA/Ma Kelas X Kelompok Wajib Semester kurikulum 2013 (Taryo, M. Darmanto, \& B. Sutrisno, eds.). Jakarta: Jakarta : Penerbit Erlangga.

Tosuncuoglu, I. (2018). Place of critical thinking in EFL. International Journal of Higher Education, 7(4), 26-32. https://doi.org/10.5430/ijhe.v7n4p26

Wahyudi, \& Anugeraheni, I. (2017). Strategi Pemecahan Masalah Matematika (Cetakan Pe). Salatiga: Satya Wacana University Press.

Wulandari, T. S. H., Amin, M., Zubaidah, S., \& IAM, M. H. (2017). Students' Critical Thinking Improvement Through PDEODE and STAD Combination in The Nutrition and Health Lecture. International Journal of Evaluation and Research in Education (IJERE), 6(2), 110-117. https://doi.org/10.11591/ijere.v6i2.7589

Zakiyah, S., Hidayat, W., \& Setiawan, W. (2019). Analisis Kemampuan Pemecahan Masalah dan Respon Peralihan Matematik dari SMP ke SMA pada Materi SPLTV. Mosharafa: Jurnal Pendidikan Matematika, 8(2), 227-238. https://doi.org/10.31980/mosharafa.v8i2.437

ŽivkoviL, S. (2016). A Model of Critical Thinking as an Important Attribute for Success in the 21st Century. Procedia - Social and Behavioral Sciences, 232(April), 102-108. https://doi.org/10.1016/j.sbspro.2016.10.034 